\title{
NEW PCR MULTIPLEXES FOR SEX TYPING OF OSTRICHES
}

\author{
MALAGÓ-JR., W. ${ }^{1}$, MEDAGLIA, A. ${ }^{2}$, MATHEUCCI-JR., E. ${ }^{2}$ \\ and HENRIQUE-SILVA, F. ${ }^{1}$ \\ ${ }^{1}$ Department of Genetics and Evolution, Federal University of São Carlos, \\ Rodovia Washington Luis, Km 235, CEP 13565-905, São Carlos, SP, Brazil \\ ${ }^{2}$ DNA Consult Genetics and Biotechnology, Rua São Paulo, 557, CEP 13560-160, São Carlos, SP, Brazil \\ Correspondence to: Flávio Henrique Silva, Department of Genetics and Evolution, Federal University of São Carlos, \\ Rodovia Washington Luis, Km 235, CEP 13565-905, São Carlos, SP, Brazil, e-mail: dfhs@ power.ufscar.br \\ Received November 17, 2004 - Accepted March 23, 2005 - Distributed November 30, 2005
}

(With 2 figures)

Determining the sex of ostriches (Struthio camelus), which is extremely important in breeding management, is a difficult task because these birds show few external differences between the sexes, especially when young. Moreover, sex identification by karyotypic analysis is impracticable since the sex chromosomes are very similar. Conventional sexing techniques are invasive and may cause stress, bleeding and infection; also, chicks must be at least 3 months old (in younger birds, the rate of error may reach up to around $40 \%$ ). Over the last few years, several reports have described PCR-based methods to sex-type ostriches (Griffiths \& Orr, 1999; Bello \& Sánchez, 1999). A method by which small female-specific PCR bands are produced was established by (Griffiths \& Orr, 1999). Another method uses sex-specific primers for a larger female fragment associated with internal standard primers in amplification reactions (Bello \& Sánchez, 1999). More recently, a paper described the establishment of a ratite-specific test (Huynen et al., 2002). These methods, which involve the use of DNA extracted from blood, have not yet been adapted for largescale analyses. A PCR-based method for largescale analyses using DNA extracted from feather bulbs was recently described (Malagó-Jr et al., 2002). In this work, a group of 100 chicks (5 days old) was subjected to previous sex-typing tests, as described (Malagó-Jr et al., 2002), after which they were subjected to gender identification using the new PCR multiplexes presented in this paper. An analysis based on the use of both duplex and triplex sex-typing methods led to the $100 \%$ accurate identification of the animals' sex. Furthermore, with the development of these new multiplexes, we confirmed a hypothetical sequence deposited in GenBank as being a female-specific marker.
The genomic DNA template was isolated from a single feather bulb (Malagó-Jr et al., 2002) or from a blood sample (Bello \& Sánchez, 1999) of each individual. All the PCR multiplex reactions were carried out in a final volume of $15 \mu \mathrm{l}$ containing approximately $10 \mathrm{ng}$ of prepared DNA template, 3 pmol of each primer, $0.5 \mathrm{U}$ of Taq DNA polymerase (Amershan Biosciences), $10 \mathrm{mM}$ Tris- $\mathrm{HCl} \mathrm{pH} \mathrm{9.0,} 1.5 \mathrm{mM} \mathrm{MgCl}_{2}, 50 \mathrm{mM} \mathrm{KCl}$, and $37.5 \mathrm{mM}$ of each dNTP. The protocol was performed using an MJ Research PTC-100 thermal cycler, starting with a heating temperature of $95^{\circ} \mathrm{C}$ for $2 \mathrm{~min}$, followed by thirty cycles of $40 \mathrm{~s}$ at $94{ }^{\circ} \mathrm{C}, 40 \mathrm{~s}$ at $54{ }^{\circ} \mathrm{C}$ and $1 \mathrm{~min}$ at $72{ }^{\circ} \mathrm{C}$. A final extension phase was carried out for $5 \mathrm{~min}$ at $72{ }^{\circ} \mathrm{C}$. The amplified products were analyzed in $1.5 \%$ agarose gel stained with ethidium bromide.

For duplex reactions (Fig. 1), we designed the new sex-specific primers OSFES-F and OSFES-R (Table 1), which amplify a fragment of a putative female-specific DNA sequence (GenBank accession number AF513225). In triplex reactions (Fig. 2), the female-specific primers SS1 and SS2 (Bello \& Sánchez, 1999) were used together with the OSFES pair (Table 1). In addition to selected female-specific PCR products, all the multiplex reactions were carried out with an internal preselected PCR control produced by VIAS-OS14f and VIAS-OS14r primers (Kumari \& Kemp,1998) (Table 1), which amplify a microsatellite region. The birds' sex was determined correctly with minimal effort simply by observing the male or female pattern of DNA bands (Figs. 1 and 2). Duplex reactions appear to be a good choice for sex analysis, since the PCR products were easily viewed (Fig. 1). However, the triplex reactions proved more effective because of the assurance 


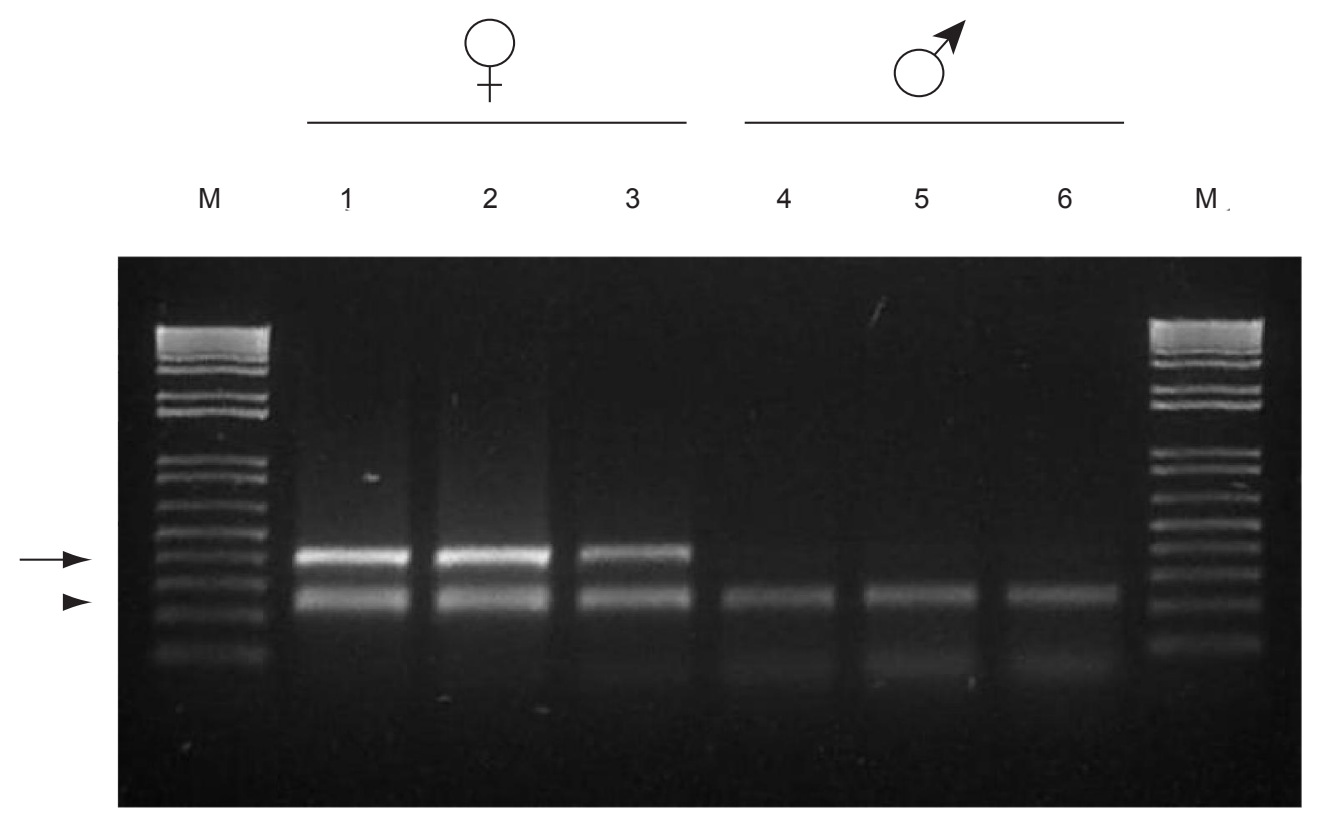

Fig. 1 - Duplex PCR-based sex-typing tests with OSFES and VIAS-OS14 primer pairs. M = Marker $1 \mathrm{~Kb}$ plus; lanes 1, 2 and 3: DNA bands from three females; lanes 4, 5 and 6: DNA bands from three males. The arrow indicates the female-specific bands (400 bp). The arrow head indicates the control.

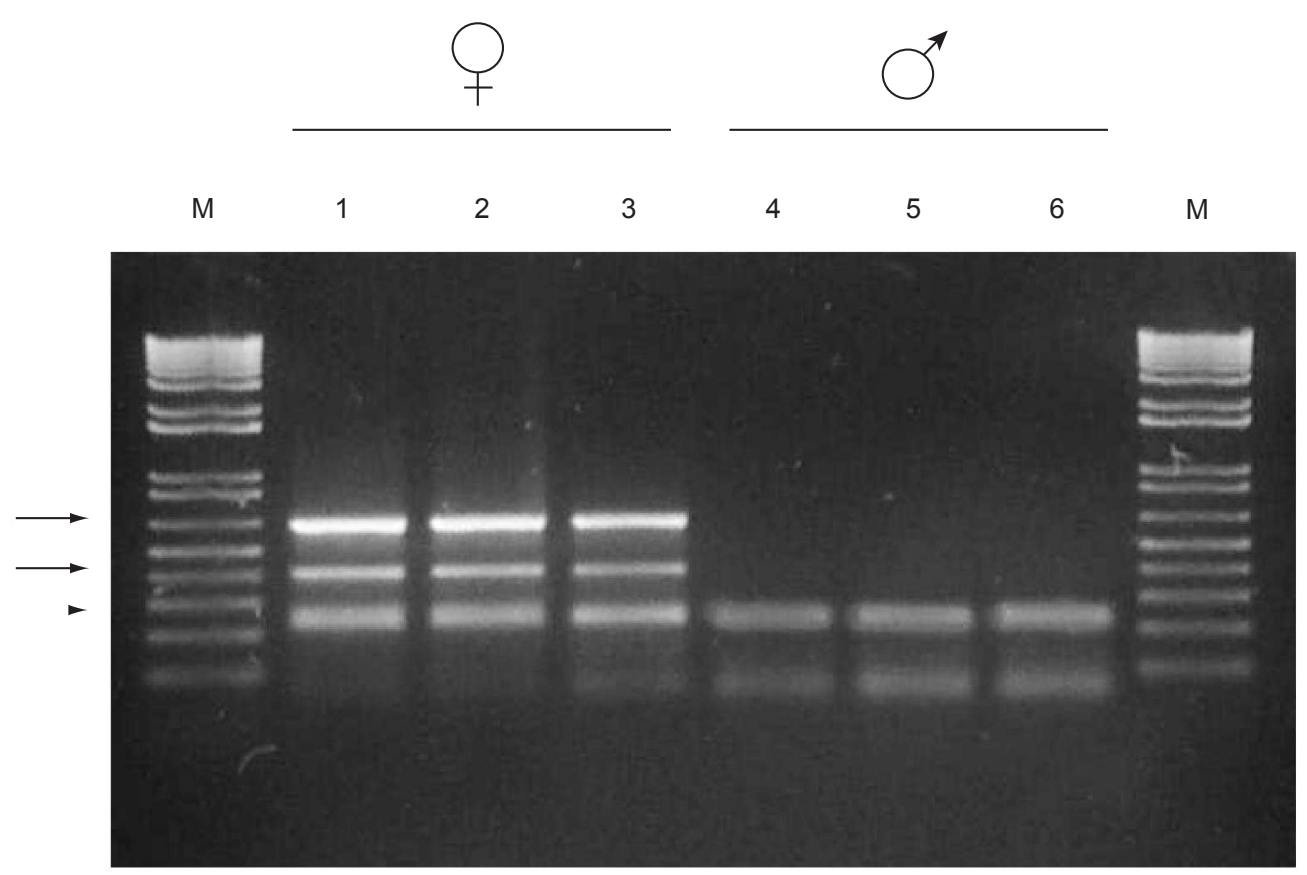

Fig. 2 - Triplex PCR-based sex-typing tests with OSFES, SS and VIAS-OS14 primer pairs. M = Marker $1 \mathrm{~Kb}$ plus; lanes 1, 2 and 3: DNA bands from three females; lanes 4, 5 and 6: DNA bands from three males. The arrows indicate the female-specific bands (SS pair $600 \mathrm{bp}$ and OSFES pair $400 \mathrm{bp}$ ). The arrow head indicates the control. 
TABLE 1

Sequences of primers used in multiplex reactions and sizes of their PCR products.

\begin{tabular}{|l|l|l|l|}
\hline Primer pairs & \multicolumn{1}{|c|}{ Forward primers } & \multicolumn{1}{c|}{ Reverse primers } & \multicolumn{1}{c|}{$\begin{array}{l}\text { Product } \\
\text { size (bp) }\end{array}$} \\
\hline OSFES & AGCAGAATTGCTGAGTAAAC & ACAGAGGTTAAAAAACCACC & 432 \\
\hline SS & TCTACACCTAAGGAGTCCCATATT & GGTCTACACCTGTTGAAAATCATT & 648 \\
\hline VIAS-OS14 & CACTTCTCCGAATTTAAAAAGG & AGGAAGAGATGTGGAGTCCC & $209-245$ \\
\hline
\end{tabular}

provided by the presence of two female-specific DNA bands (Fig. 2). The method developed in this study is inexpensive, accurate and requires a minimum of specialized equipment. Furthermore, it can be performed on chick feathers, providing an early diagnosis, and is useful for sex identification in the first days of nestling life. Finally, our findings demonstrate that the sequence deposited in GenBank (accession number AF513225) can indeed be used as a female-specific marker and, hence, for ostrich sex-typing.

Acknowledgements - The authors thank Mr. Ariovaldo de Freitas of the Três Irmãs farm (Samua Comercial Ltda.), Araraquara, SP, Brazil, for providing ostrich feathers. This research was supported by DNA Consult Genetics and Biotechnology S/C Ltda., São Carlos, SP, Brazil and FAPESP (PIPE 01/08612-8) (Brazil).

\section{REFERENCES}

BELLO, N. \& SÁNCHEZ, A., 1999, The identification of a sex-specific DNA marker in the ostrich using a random amplified polymorphic DNA (RAPD) assay. Mol. Ecology, $8(4), 667-669$.

GRIFFITHS, R. \& ORR, K., 1999, The use of amplified fragment length polymorphism (AFLP) in the isolation of sex-specific markers. Mol. Ecology, 8(4): 671-674.

HUYNEN, L. MILLAR, C. D. \& LAMBERT, D. M., 2002, A DNA test to sex ratite birds. Mol. Ecology 11(4), 851-856.

KUMARI, P. \& KEMP S. J., 1998, Polymorphic microsatellite markers in the ostrich (Struthio camelus). Mol. Ecology, 7, 133-140.

MALAGÓ-Jr, W., FRANCO, H. M., MATHEUCCI-Jr, E., MEDAGLIA, A. \& HENRIQUE-SILVA, F., 2002, Large scale sex typing of ostriches using DNA extracted from feathers. BMC Biotechnol, 2(1), 19. 